\title{
Effects of temperature, stocking density and farming conditions on fin damage in European sea bass (Dicentrarchus labrax)
}

\author{
Jeannine Person-Le Ruyet ${ }^{\mathrm{a}}$ and Nicolas Le Bayon \\ Ifremer, Centre de Brest, Physiologie fonctionnelle des Organismes marins, UMR 1067, BP 70, 29280 Plouzané, France
}

Received 5 May 2009; Accepted 2 October 2009

\begin{abstract}
This paper presents a non invasive, rapid and reliable way to quantitatively assess fin erosion in sea bass (Dicentrarchus labrax). The method is based on a visual assessment of fin profile and area loss of all fins except the anterior dorsal, on a scale from 0 to 4 in comparison with a perfect fin. The effects of stocking density (SD) and temperature on fin damage were investigated under experimental conditions (100-250 g fish). Over a 4-month period, mean erosion index (mean erosion level of all fins) was 10 times higher at 120 than at $20 \mathrm{~kg} \mathrm{~m}^{-3}$, where most fins were undamaged. Damage was also dependent on time and oxygen concentration $\left(35 \%\right.$ lower at $53 \% \mathrm{O}_{2}$ saturation than at $105 \%$ ). Fin condition was also affected by temperature: mean erosion index was $0.22-0.25$ at $13-16{ }^{\circ} \mathrm{C}$, but five times higher at $25{ }^{\circ} \mathrm{C}$. Caudal and dorsal fins were always the most eroded. Fin damage was then monitored in a large land-based farm using high SD, and in a small sea cage farm operating at low SD. At the first site, 6 batches of two market size groups were examined: L $\left(850-930 \mathrm{~g}, 50-80 \mathrm{~kg} \mathrm{~m}^{-3}\right)$ and $\mathrm{S}\left(375-400 \mathrm{~g}, 42-60 \mathrm{~kg} \mathrm{~m}^{-3}\right)$. Fin condition was good in all batches (mean erosion index, 1.1-1.3) and lowest at the highest SD. At the second site, four batches of large fish (350-890 g, 26-24 $\left.\mathrm{kg} \mathrm{m}^{-3}\right)$ and four other groups below market size (100-270 g, 8-16 kg m${ }^{-3}$ ) were examined. Fin erosion was the highest in large fish (mean erosion index, 1.1-1.2) and in the sea cages most exposed to climatic disturbances. In both sites, the most eroded fins were the caudal and dorsal. Differences in other external injuries were also observed between the two sites (less necrosis and more scale injuries in sea cages). The causes of fin damage are discussed in relation to metabolic and/or behavioral adaptations to rearing conditions and the main actions that could be taken to improve fin condition are discussed.
\end{abstract}

Key words: Sea bass / Fin damage / Welfare / Temperature / Stocking density / Rearing systems

Résumé - Cet article décrit une méthode conservative, rapide et fiable pour quantifier l'érosion des nageoires de bar (Dicentrarchus labrax). Elle est basée sur l'évaluation visuelle du profil et de la réduction de taille de toutes les nageoires sauf la dorsale antérieure, sur une échelle de 0 à 4 en comparaison avec une nageoire parfaite. Les effets de la densité de stockage (SD) et de la température sur l'état des nageoires sont évalués expérimentalement (poissons de 100-250 g). Après 4 mois, l'index moyen d'érosion (niveau moyen d'érosion de toutes les nageoires) est 10 fois plus élevé à 120 qu'à $20 \mathrm{~kg} \mathrm{~m}^{-3}$ où la plupart des nageoires est intègre. La perte d'intégrité est dépendante du temps et de la concentration en oxygène ( $35 \%$ plus faible à 53 qu'à $105 \%$ de saturation en $\mathrm{O}_{2}$ ). L'état des nageoires est aussi affecté par la température : index moyen d'érosion de $0,22-0,25$ à $13-16^{\circ} \mathrm{C}$, mais 5 fois plus élevé à $25^{\circ} \mathrm{C}$. Les nageoires les plus érodées sont la caudale et la dorsale postérieure. L'état des nageoires est aussi évalué d'une part, dans une ferme d'élevage de grande taille utilisant des bassins et des densités élevées et d'autre part, dans une ferme de petite taille utilisant des cages et de faibles densités. Sur le premier site, 6 lots de taille commerciale sont examinés : L (850-930 g, 50-80 $\left.\mathrm{kg} \mathrm{m}^{-3}\right)$ et S (375-400 g, 42-60 $\mathrm{kg} \mathrm{m}^{-3}$ ). L'état des nageoires est bon dans tous les lots (index moyen d'érosion, 1,1 à 1,3 ) et moindre aux densités élevées. Dans le second site, 4 lots de poissons de grande taille (350-890 g, 26-24 $\left.\mathrm{kg} \mathrm{m}^{-3}\right)$ et 4 lots en dessous de la taille commerciale (100-270 g, 8-16 kg m$\left.{ }^{-3}\right)$ sont examinés. L'érosion des nageoires est la plus forte chez les gros poissons (niveau moyen d'érosion, 1,1-1,2) et dans les cages les plus exposées aux perturbations climatiques. Dans les deux sites, les nageoires les plus érodées sont la caudale et la nageoire dorsale postérieure. Des différences de l'état apparent des poissons sont aussi observées entre les deux sites (moins de nécroses et plus de lésions des écailles chez les poissons en cage). Les causes des lésions des nageoires sont discutées, en relation avec les ajustements du métabolisme et/ou du comportement aux conditions d'élevage, ainsi que les principales actions à mettre en œuvre permettant d'améliorer l'état des nageoires.

\footnotetext{
a Corresponding author:

jperson@ifremer.fr, jeannine.person@orange.fr
} 


\section{Introduction}

Fish maintain their position in water and cope with their environment through constant adjustments of swimming activity. The role of different fins in propulsion and manoeuvring is shared in a complex manner between the paired and median fins. In the wild, as on farms, fish are exposed to factors that may damage their fin tissues (erosion, necrosis, splitting or fin tissue losses). Such damage may result from physical or chemical causes or from disease (see Ellis et al. 2008 for review). Because fin profile changes are visible and potentially easy to quantify, fin condition has long been considered as a useful indicator of fish health status. For re-stocking programs, relative fin length is commonly used as an indicator of juvenile quality as it is highly affected by rearing conditions such as substrate, temperature, water quality, feeding and water velocity (Wagner et al. 1996; Winfree et al. 1998; Barrows and Lellis 1999; Arndt et al. 2002; Pelis and McCormick 2003; Ellis et al. 2009). The pathology of fin erosion has been described in many species and sometimes using other organismic indices; fin injuries are commonly used to score fish health condition on farms (Goede and Barton 1990; Turnbull et al. 1996; Latremouille 2003; St-Hilaire et al. 2006). Fin condition can also provide a relatively simple and rapid indicator of fish welfare, relating to the quality of life or state of well being of fish (Conte 2004; Huntingford et al. 2006; Ashley 2007). Fin condition is potentially better in the wild than in intensive farming where, in both aggressive and non aggressive fish, the main risk factors are stocking density, water quality, feeding and routine handling (Moutou et al. 1998; MacLean et al. 2000; Latremouille 2003; North et al. 2006a,b; Rasmussen et al. 2007; Hoyle et al. 2007; Ellis et al. 2008).

In intensive aquaculture, studies on the frequency and severity of fin damage and its causes have focused on salmonids that are commonly affected both in freshwater and sea water (Turnbull et al. 1998; North et al. 2006a,b; St-Hilaire et al. 2006; Rasmussen et al. 2007; Noble et al. 2007, 2008; Person-Le Ruyet et al. 2008; Ellis et al. 2008; Good et al. 2009; Roque et al. 2009; Korsoen et al. 2009). In rainbow trout (Oncorhynchus mykiss) farms, St-Hilaire et al. (2006) showed that fin injuries were dependent on fish size, that the pectoral and dorsal fins were the most eroded and that there was high variability between individuals and different farms. In species where aggression is common, any factors that increase competition between fish, such as size heterogeneity, restricted feeding and feeding method, will increase fin damage, as shown in Arctic charr (Salvelinus alpinus) (Damsgard et al. 1997), Atlantic salmon (Salmo salar) (Turnbull et al. 2005; Noble et al. 2007a, 2008) and rainbow trout (Noble et al. 2007b). In rainbow trout fed to satiety, we previously showed that the frequency and prevalence of damage to dorsal and pectoral fins was influenced by stocking density (damage increased as stocking density, SD, increased), water quality (more damage where water quality promoted feeding activity) and fish size (higher in large fish), indicating that fin condition may be affected by crowding, metabolic activity or both (Person-Le Ruyet et al. 2008). In the same species, fin erosion was seen to be lower in a flow-through system rather than a re-circulated system with a higher water velocity (Roque et al. 2009). Using re-circulated systems, Good et al. (2009) showed that for unexplained reasons a poorer caudal fin condition was associated with a low water exchange rate.

Studies on fin damage in other farmed fish species are scarce. In cod (Gadus morhua) juveniles, it has been shown that the incidence of fin damage caused by aggressive behaviour was high and increased significantly under restricted feeding (Hatlen et al. 2006). To our knowledge, when recent studies looked at sea bass (Dicentrarchus labrax) or sea bream (Sparus aurata) welfare status in relation to stocking density or stress conditions, they have not included fin damage in their lists of direct or indirect welfare indicators, but have concentrated on growth performances, blood parameters and tissue composition (Roncarati et al. 2006; Di Marco et al. 2008; Sammouth et al. 2009).

The purpose of this study was to investigate the effects of some environmental risk factors (temperature and SD) on fin damage under controlled experimental conditions. This first required us to develop a method for assessing fin erosion in juvenile and adult sea bass. Fin damage was then monitored on two farms representing extreme rearing conditions: a landbased farm producing 1500 tons of sea bass per year at high SD and a sea cage farm producing less than 100 tons of organic fish per year. The direct causes of fin damage related to rearing conditions are discussed with regard to possible welfare actions that may be taken to improve fin condition and enhance fish welfare.

\section{Material and methods}

\subsection{Fin damage assessment method}

To understand the mechanisms and kinetics of fin erosion, several thousand juveniles and adults from different origins (pond culture, experiments or wild fish) were examined using a method previously described for rainbow trout (Person-Le Ruyet et al. 2007).

Fish were anesthetized (ethylene glycol monophenyl ether, $0.2-0.5 \%$ ) prior to examination for fin erosion, other fin damage and skin injuries in a representative sample of fish (30 fish under experimental conditions and 50 fish minimum under farming conditions, to limit any possible bias of the sampling procedure).

Fin erosion was defined as a change in total fin area and was estimated by fin profile comparison against a perfect fin (Fig. 1) and discussed in results. The erosion parameters are calculated from erosion levels of all fins as follows.

- Erosion index per condition: mean erosion level of the 7 fins of all fish sampled per experimental condition and per sampling date;

- Erosion level per fin: mean erosion level of a specific fin of all fish examined per experimental condition;

- Erosion occurrence: the relative frequency of the 5 erosion levels recorded in all fins of all fish examined per experimental condition.

Under farming conditions, a splitting index was calculated for all fins and for the caudal fin separately, as follows. 


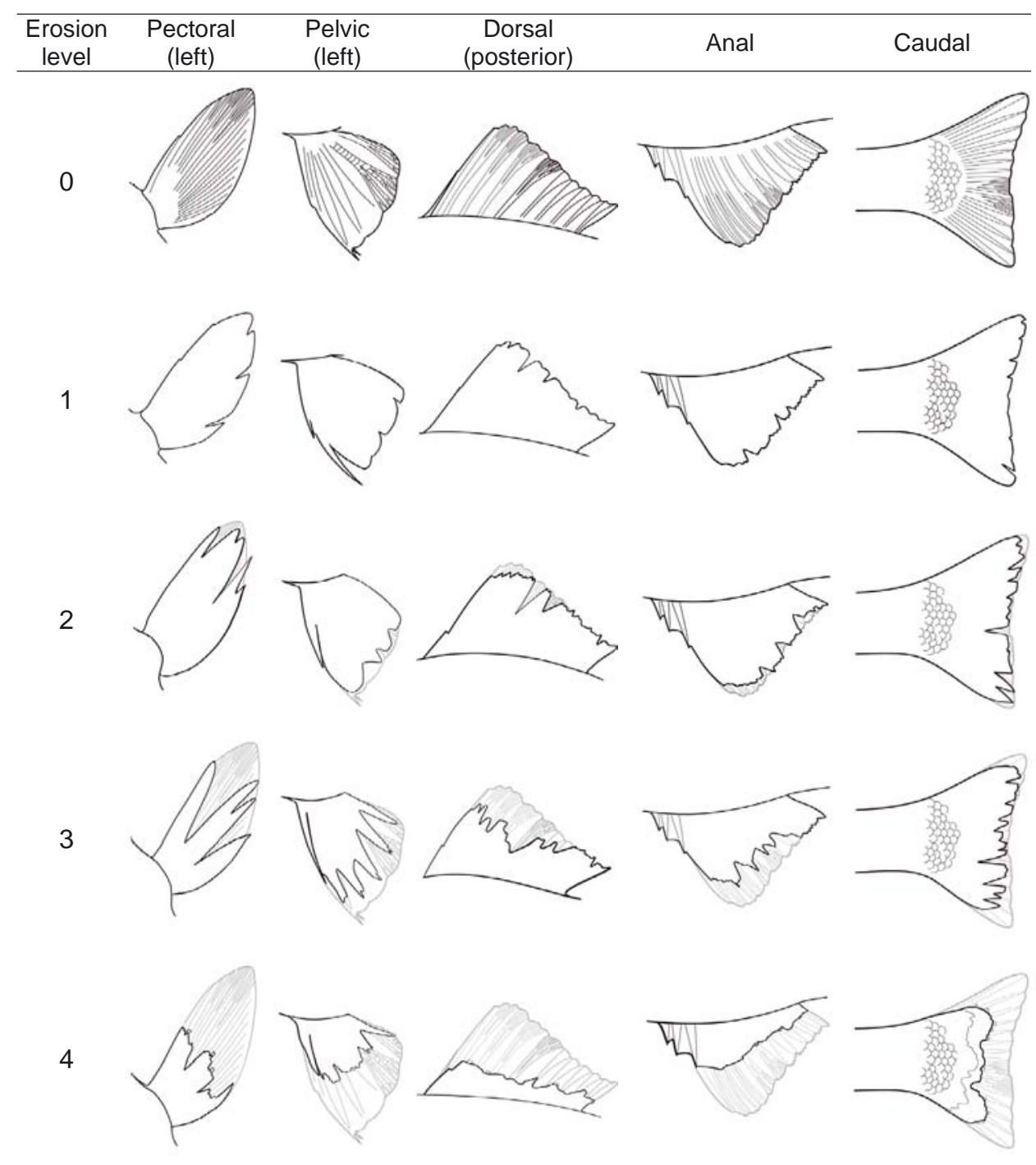

Fig. 1. Changes in profile of median and paired fins used to identify the 5 erosion levels for sea bass juveniles and adults.

- Splitting index per fish: mean number of splits per fish calculated for all fins of all fish sampled from each of the production conditions;

- Caudal splitting index: mean number of splits of a specific fin of all fish examined in each of the production conditions.

\subsection{Assessment of potential risks factors under experimental conditions}

The long-term effects of two factors, stocking density (SD) and temperature, that can cause damage to sea bass fins were investigated under experimental conditions using flow through systems and $0.5 \mathrm{~m}^{-3}$ square tanks. The photoperiod was maintained at 18L:6D and maximum light intensity was 50 lux at the water surface. The exchange Fish were fed a commercial extruded diet (Le Gouessant $($ ), protein $44.1 \%$ and crude fat $22.5 \%$ ) to apparent satiety.

\subsubsection{Stocking density}

Sea bass (initial weight, $180 \mathrm{~g}$ ) were held for 4 months at low or SD that increased from 12 to $20 \mathrm{~kg} \mathrm{~m}^{-3}$ or from 91 to $118 \mathrm{~kg} \mathrm{~m}^{-3}$ over the course of the experiment (groups marked with the prefix 20 or 120 in Table 1). Each group was divided into high and low $\mathrm{O}_{2}$ concentration sub-groups (Ho and Lo) where $\mathrm{O}_{2}$ concentration was checked daily prior to feeding and adjusted to SD when necessary using either water near $\mathrm{O}_{2}$ saturation or water supplemented with $\mathrm{O}_{2}$ using the device described in Person-Le Ruyet et al. (2002), i.e. pure oxygen injection in desaturated sea water. In Ho groups, water flow rate was $330 \%$ per hour at $20 \mathrm{~kg} \mathrm{~m}^{-3}$ and $440 \%$ per hour at $120 \mathrm{~kg} \mathrm{~m}^{-3}$. The $\mathrm{O}_{2}$ concentrations achieved at low SD were 102 or $80 \%(\mathrm{pH}, 8.0)$ for Ho and Lo, respectively, and at high SD they were 106 or $53 \%$ (pH was lower in Ho than in Lo, 7.4 and 7.7, respectively). Temperature was $19 \pm 0.01{ }^{\circ} \mathrm{C}$ (SE) and fish were fed a fixed diet, regularly adjusted to fish demand and provided by an automatic feeder. The 4 experimental 
Table 1. Data (mean $\pm \mathrm{SE}$ ) to fish and water quality in the stocking density experiment. Means are given with $\mathrm{SE}$; fish weight, $n=30$; $\mathrm{O}_{2}$ concentrations, $n=102 ; \mathrm{pH}, n=15$.

\begin{tabular}{|c|c|c|c|c|c|c|}
\hline $\begin{array}{l}\text { Growing } \\
\text { conditions }\end{array}$ & Day & $\begin{array}{c}\text { Stocking density } \\
\left(\mathrm{kg} \mathrm{m}^{-3}\right)\end{array}$ & $\begin{array}{c}\mathrm{O}_{2} \\
(\%)\end{array}$ & $\mathrm{pH}$ & $\begin{array}{l}\text { Weight } \\
(\mathrm{g})\end{array}$ & $\begin{array}{c}\text { Survival } \\
(\%)\end{array}$ \\
\hline \multirow[t]{3}{*}{ 20-Но } & 0 & 12.0 & \multirow{3}{*}{$102 \pm 0.7$} & \multirow{3}{*}{$8.0 \pm 0.01$} & $179.9 \pm 4.5$ & \\
\hline & 92 & 17.2 & & & $257.7 \pm 5.8$ & 100 \\
\hline & 114 & 20.3 & & & $305.2 \pm 8.1$ & 100 \\
\hline \multirow[t]{3}{*}{ 20-Lo } & 0 & 12.9 & \multirow{3}{*}{$80 \pm 0.2$} & \multirow{3}{*}{$8.0 \pm 0.01$} & $193.3 \pm 5.8$ & \\
\hline & 92 & 18.7 & & & $301.3 \pm 9.5$ & 100 \\
\hline & 114 & 20.6 & & & $330.4 \pm 10.1$ & 100 \\
\hline \multirow[t]{3}{*}{ 120-Ho } & 0 & 90.9 & \multirow{3}{*}{$106 \pm 1.2$} & \multirow{3}{*}{$7.4 \pm 0.02$} & $185.1 \pm 5.6$ & \\
\hline & 92 & 121.7 & & & $247.8 \pm 7.3$ & 99 \\
\hline & 114 & 118.3 & & & $244.5 \pm 6.8$ & 98 \\
\hline \multirow[t]{3}{*}{ 120-Lo } & 0 & 90.9 & \multirow{3}{*}{$53 \pm 1.8$} & \multirow{3}{*}{$7.7 \pm 0.01$} & $177.1 \pm 5.8$ & \\
\hline & 92 & 118.3 & & & $230.4 \pm 5.5$ & 99 \\
\hline & 114 & 120.1 & & & $234.0 \pm 6.6$ & 99 \\
\hline
\end{tabular}

conditions were thus 20-Lo, 20-Ho, 120-Lo and 120-Ho (no replicate).

At days 92 and 114, all fins except the anterior dorsal were examined by a single operator in 30 fish per tank (210 fins total) to quantify the erosion level per fin and calculate the different erosion indices. At the start of the experiment fin condition was high and similar in all groups.

\subsubsection{Temperature}

Duplicated groups of sea bass juveniles (initially 84 fish) were reared at 6 constant temperatures $(13,16,19,22,25$ or $29^{\circ} \mathrm{C}$ ) for 84 days (Table 2). They were maintained under $\mathrm{O}_{2}$ concentrations close to saturation using water supplemented with oxygen as in the previous experiment and a exchange rate of $160 \% \mathrm{~h}^{-1}$ to secure a high water quality in all groups. All fish were weighed every two weeks for growth performances, some individuals were sampled regularly to assess health status and their removal allowed us to maintain stocking density below $30 \mathrm{~kg} \mathrm{~m}^{-3}$ (for details see Person-Le Ruyet et al. 2004).

At day 84 , fin damage was assessed in 40 fish per temperature treatment $(6 \times 280$ fins total $)$.

\subsection{Fin damage monitoring under production conditions}

Fin damage and other external injuries were monitored in two sea bass farms representative of intensive and extensive production in France. The first was a large land-based farm using flow-through systems and high stocking density, and the second a small farm producing organic fish in sea cages located in the open sea.

\subsubsection{Intensive land-based farm}

The selected land-based farm is the French leader for sea bass and sea bream production (2500 tons per year total, $60 \%$ sea bass). It is supplied with heated industrial water and operates at a final stocking density around $60 \mathrm{~kg} \mathrm{~m}^{-3}$.
Two market size classes of sea bass were selected ( $\mathrm{S}$ and L: about 400 and $1000 \mathrm{~g}$, respectively) provided by the same hatchery (Table 3 ). Fish were held under usual farm conditions until sampling: $160 \mathrm{~m}^{3}$ raceway tanks, $21.4{ }^{\circ} \mathrm{C}, \mathrm{O}_{2}$ near saturation and feeding using automatic feeding devices with computer monitoring. The production cycle was 54 weeks for $400 \mathrm{~g}$ fish and 97 weeks for $1 \mathrm{~kg}$ fish. There were no major seasonal growth disturbances within the annual temperature range, $16.5-25{ }^{\circ} \mathrm{C}$. In each of the 6 batches monitored ( 3 for the $\mathrm{S}$ group and 3 for the L group), 50 fish were randomly sampled and examined for fin damage (erosion, splitting, ray deformity or necrosis) and other external injuries (scale marks).

Results were recorded for each size class ( $\mathrm{S}$ or $\mathrm{L}$ ) and stocking density (represented by suffix number in Table 3). Condition factor was calculated as weight " $\mathrm{L}^{-3}$."

\subsubsection{Sea cage farm}

Fin damage was assessed in a second farm using floating sea cages located in a sheltered Mediterranean bay exposed to Eastern storms for 80 days per year. This certified organic fish farm produces less than 100 tons per year in open sea conditions at low stocking density, $25 \mathrm{~kg} \mathrm{~m}^{-3}$ maximum at the end of the production cycle.

Eight batches of fish, initially supplied by a common local hatchery at 5-10 g, were compared according to fish size (100$900 \mathrm{~g})$, cage volume ( 80 and $100 \mathrm{~m}^{3}$ ) and location in the bay (exposure to water currents and storms with high winds). In each cage, 50 fish were randomly sampled, anesthetized prior to overland transport (in water supplemented with oxygen) and examined for fin damage and other external injuries.

Main batch characteristics are given according to fish weight and time spent on site, i.e. 10 to 41 months (Table 5). Mean annual temperature was $16.5^{\circ} \mathrm{C}$ (extremes: 11.2 and $24.7^{\circ} \mathrm{C}$ ). As growth stops completely for $4-5$ months per year, 3 summers are required to produce $1 \mathrm{~kg}$ fish. During the production cycle, fish were graded at 100 and $200 \mathrm{~g}$ in order to limit fish crowding and related stress during handling. Fish are fed by hand on demand and the number of meals per day adjusted according to climatic conditions. 
Table 2. Data related to fish and water quality in the temperature experiment. Means are given with SE; day 0 fish weight, $n=168$ and day 84 , $n=104 ; \mathrm{O}_{2}$ concentrations, $n=84 ; \mathrm{pH}, n=12$.

\begin{tabular}{|c|c|c|c|c|c|c|}
\hline \multirow{2}{*}{$\begin{array}{c}\text { Temperature } \\
\left({ }^{\circ} \mathrm{C}\right) \\
\text { Day 0-84 }\end{array}$} & \multicolumn{2}{|c|}{$\begin{array}{c}\text { Mean weight } \\
\text { (g) }\end{array}$} & \multicolumn{2}{|c|}{$\begin{array}{l}\text { Stocking density } \\
\left(\mathrm{kg} \mathrm{m}^{-3}\right)\end{array}$} & \multirow{2}{*}{$\begin{array}{c}\mathrm{O}_{2} \\
(\%) \\
\text { Day } 0-84\end{array}$} & \multirow{2}{*}{$\begin{array}{c}\mathrm{pH} \\
\text { Day 0-84 }\end{array}$} \\
\hline & Day 0 & Day 84 & Day 0 & Day 84 & & \\
\hline $13.4 \pm 0.1$ & $81.3 \pm 1.1$ & $118.9 \pm 2.3$ & 16.3 & 14.7 & $96 \pm 8$ & $8.20 \pm 0.02$ \\
\hline $16.2 \pm 0.1$ & $81.4 \pm 1.0$ & $140.2 \pm 2.1$ & 16.3 & 17.4 & $104 \pm 8$ & $8.15 \pm 0.07$ \\
\hline $18.9 \pm 0.1$ & $81.9 \pm 1.0$ & $179.1 \pm 3.4$ & 16.4 & 22.2 & $109 \pm 9$ & $8.10 \pm 0.02$ \\
\hline $21.9 \pm 0.1$ & $80.7 \pm 1.0$ & $209.5 \pm 3.8$ & 16.1 & 25.9 & $106 \pm 8$ & $8.02 \pm 0.03$ \\
\hline $24.9 \pm 0.1$ & $81.9 \pm 1.1$ & $241.4 \pm 4.7$ & 16.4 & 29.9 & $107 \pm 10$ & $7.97 \pm 0.03$ \\
\hline $28.8 \pm 0.1$ & $82.6 \pm 1.0$ & $227.4 \pm 5.0$ & 16.5 & 28.1 & $109 \pm 8$ & $7.96 \pm 0.03$ \\
\hline
\end{tabular}

Table 3. Main characteristics of fish examined according to production conditions in tanks. Mean weight is given with SE $(n=50)$.

\begin{tabular}{ccccccc}
\hline Size & Batch & Volume $\left(\mathrm{m}^{3}\right)$ & $\begin{array}{c}\text { Mean weight } \\
\mathrm{g})\end{array}$ & $\begin{array}{c}\text { Fish } \\
\text { number }\end{array}$ & $\begin{array}{c}\text { Stocking density } \\
\left(\mathrm{kg} \mathrm{m}^{-3}\right)\end{array}$ & $\begin{array}{c}\text { Time from last grading } \\
(\text { week })\end{array}$ \\
\hline \multirow{3}{*}{$\mathrm{S}$} & S42 & 140 & $401 \pm 13$ & 16740 & 42 & 11 \\
& S48 & 178 & $427 \pm 11$ & 17324 & 48 & 5 \\
& S58 & 196 & $375 \pm 9$ & 24948 & 58 & 4 \\
\hline \multirow{2}{*}{ L } & L49 & 149 & $927 \pm 26$ & 8127 & 49 & 25 \\
& L62 & 178 & $853 \pm 20$ & 11705 & 62 & 51 \\
& L79 & 196 & $854 \pm 2.3$ & 14359 & 79 & 52 \\
\hline
\end{tabular}

Table 4. Additional fin and skin damage in the 6 batches examined at the land-based farm. Fish examined for whole body and all fins, $n=50$; split index is given for all fins and for caudal (bracket); necrosis occurrence is given for whole body and for all fins (bracket).

\begin{tabular}{|c|c|c|c|c|c|}
\hline \multirow[b]{2}{*}{ Size } & \multirow[b]{2}{*}{ Batch } & \multirow{2}{*}{$\begin{array}{c}\text { Split index } \\
\text { All fins (caudal) }\end{array}$} & \multicolumn{3}{|c|}{ Occurrence (\% of fish) } \\
\hline & & & $\begin{array}{c}\text { Necrosis } \\
\text { Whole body (fin) }\end{array}$ & Fin ray deformity & Scale marks \\
\hline \multirow{3}{*}{$S$} & S42 & $0.54(1.76)$ & $30(10)$ & 40 & 22 \\
\hline & S48 & $0.68(1.74)$ & $48(20)$ & 26 & 10 \\
\hline & S58 & $0.45(1.08)$ & $48(32)$ & 38 & 14 \\
\hline \multirow{3}{*}{$\mathrm{L}$} & L49 & $0.43(1.62)$ & $34(24)$ & 74 & 12 \\
\hline & L62 & $0.53(2.00)$ & $60(52)$ & 36 & 2 \\
\hline & L79 & $0.88(2.56)$ & $82(62)$ & 64 & 10 \\
\hline
\end{tabular}

\subsection{Statistical analysis}

All results were expressed as mean \pm standard error (SE). The effects of the experimental conditions tested on fin erosion parameters and all studied parameters were compared by ANOVA followed, when necessary, by a post hoc test. Under farming conditions the different batches monitored were tested by ANOVA.

\section{Results}

\subsection{Fin damage assessment method}

Sea bass have 8 fins, including 2 paired fins and 2 dorsal fins. In all fins except the anterior dorsal, the main soft rays develop several dichotomies towards the front tip; 1-3 short spiny rays are also present at one tip, except in the caudal. The anterior dorsal is short with exclusively spiny rays that are often exposed (i.e. when the tissues are stripped from the fin ray); it was excluded from erosion assessment because it is usually damaged by handling and therefore difficult to assess.
Damage first occurred in the front tip of most fins, with a progressive decrease in the length of soft rays leading to progressive loss of fin area. Fin profile alteration was different in the caudal fin, where the two external tips were first eroded. Splitting (a more or less deep cut between two rays) is common in the fins most exposed to mechanical shocks, and is explained both by fin anatomy and behavioural response to stress. It ranges from minor "V form" (recent or healed erosion) to deep splits (acute erosion) and, together with broken or missing rays, may contribute to the loss of fin area and function. Fin thickening occurs as a result of disease or healed erosion, and blood spots or necrosis are obvious signs of active erosion or infection. The prevalence of bolded rays or scale loss are noted as additional external injuries.

Fin erosion is defined as a change in total fin area due to acute or healed erosion and is estimated by fin profile comparison against a perfect fin. The method is based on a visual assessment of fin condition of all fins except the anterior dorsal, on a scale from 0 to 4 (Fig. 1). The progressive loss in fin area, as defined in Fig. 1, was estimated from image analysis, and total fin loss was calculated to determine an upper limit per erosion level:

- Level 0: perfect fin, all fins with extremities intact; 
Table 5. Main characteristics of fish examined according to production conditions in sea cages. Mean weight is given with SE ( $n=50$ ).

\begin{tabular}{ccccccc}
\hline Batch & $\begin{array}{c}\text { Volume } \\
\left(\mathrm{m}^{3}\right)\end{array}$ & $\begin{array}{c}\text { Stocking density } \\
\left(\mathrm{kg} \mathrm{m}^{-3}\right)\end{array}$ & $\begin{array}{c}\text { Mean weight } \\
(\mathrm{g})\end{array}$ & $\begin{array}{c}\text { Fish } \\
\text { number }\end{array}$ & $\begin{array}{c}\text { Time in cages } \\
(\mathrm{month})\end{array}$ & $\begin{array}{c}\text { Distance from bay } \\
\text { mouth }(\mathrm{m})\end{array}$ \\
\hline C22 & 80 & 11.2 & $101 \pm 5$ & 8915 & 10.5 & 135 \\
P11 & 200 & 8.4 & $159 \pm 3$ & 10546 & 17.6 & 101 \\
M2 & 200 & 9.0 & $196 \pm 12$ & 9120 & 17.6 & 23 \\
C15 & 80 & 16.4 & $267 \pm 5$ & 4891 & 17.6 & 116 \\
M1 & 200 & 16.6 & $358 \pm 5$ & 9260 & 22.3 & 32 \\
P7 & 200 & 15.7 & $408 \pm 25$ & 7697 & 30.1 & 73 \\
P3 & 200 & 11.3 & $474 \pm 14$ & 4752 & 30.1 & 71.1 \\
P13 & 200 & 23.7 & $885 \pm 10$ & 5366 & 41.1 & 77 \\
\hline
\end{tabular}
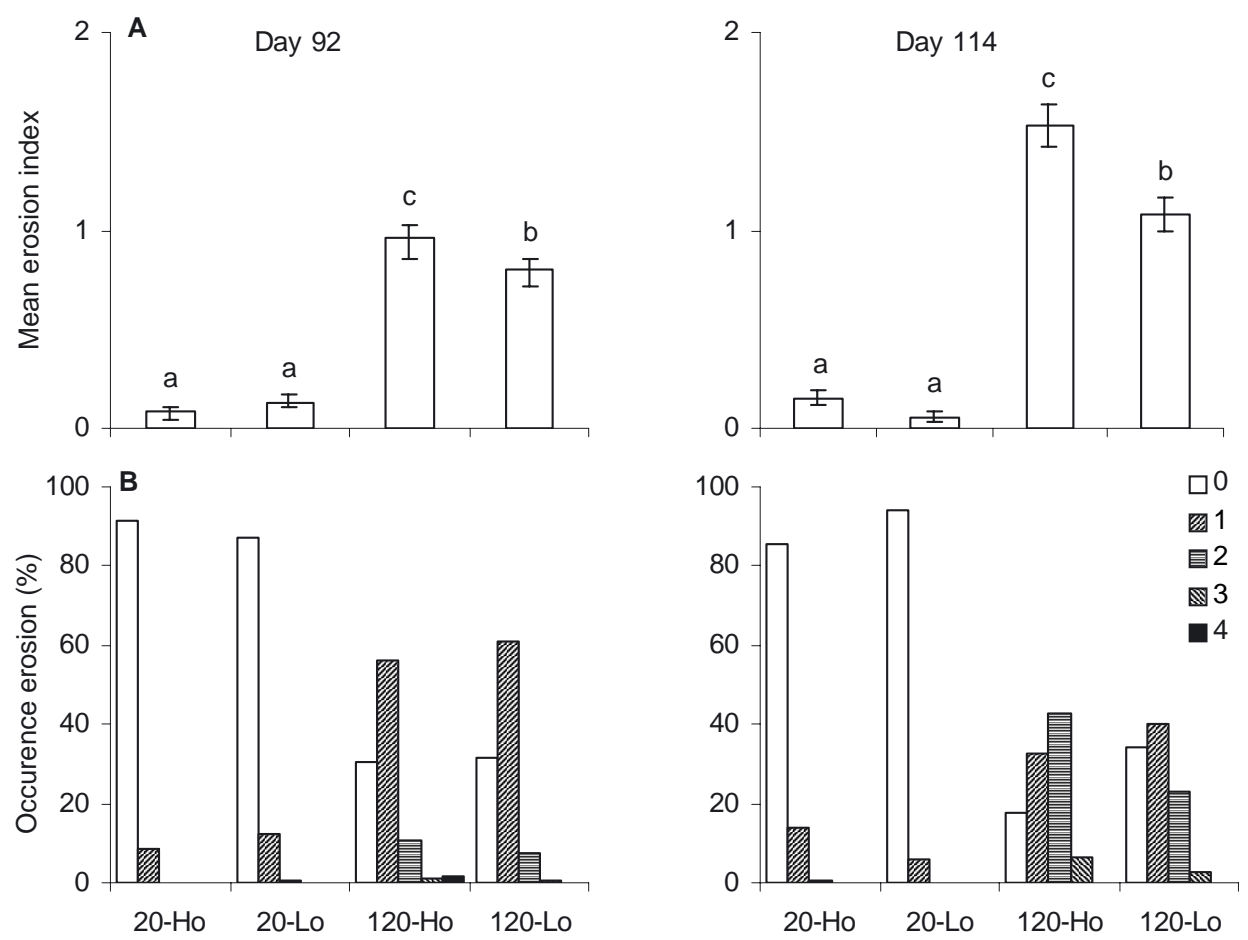

Fig. 2. Mean ( \pm SE) erosion index (A) and erosion occurrence per level (B) at days 92 and 114 in each of the experimental conditions tested: 20 and $120 \mathrm{~kg} \mathrm{~m}^{-3}$ final stocking density, and $\mathrm{Ho}$ and Lo, high and low $\mathrm{O}_{2}$ concentrations. Values with different letters at the same date are significantly different $(p<0.05)$.

- Level 1: no serious change in total fin area $(<10 \%)$, but change in fin profile with micro-splits on the front tip (indented white rings) or exceptionally one deep clean split (>1/2 fin length);

- Level 2: moderate decrease in total fin area $(<20 \%)$ without marked changes in fin profile, presence of less than 5 minor "V form" splits (depth $<1 / 3$ of fin length) or of one deep clean split ( $>1 / 3$ fin length);

- Level 3: marked decrease in total fin area $(<50 \%)$ and major changes in fin profile, with many splits ( $>5$ minor splits or at least 3 major splits), common fin thickening but absence of blood spots or necrosis;

- Level 4: short and dysfunctional fins, marked loss of total fin area (> 50\%), many major damages with extensive tissue degradation, common bleeding spots and secondary infections.

The erosion parameters are calculated from erosion levels of all fins as described in the method section.

\subsection{Assessment of potential risks factors under experimental conditions}

\subsubsection{Stocking density}

During the 4-month experiment, survival was near maximum in all groups. Growth was high at low SD where $\mathrm{O}_{2}$ concentration was higher, except in the 20-Lo group (as there was no supply in oxygen deprived water in this treatment). At high $\mathrm{SD}$, no growth had occurred by the end of the experiment irrespective of $\mathrm{O}_{2}$ concentration. In resting fish, swimming was erratic at low SD. At high SD it was organized and directed against water current.

Mean erosion index was very low at $20 \mathrm{~kg} \mathrm{~m}^{-3}$ and in the same range at day 92 and 114 for both $\mathrm{O}_{2}$ concentrations, 0.06-0.15 (Fig. 2). At day 92, it was much higher at 120 than at $20 \mathrm{~kg} \mathrm{~m}^{-3}, 0.9$ and 0.1 respectively. At high SD, mean erosion index was dependent on time and oxygen concentration: at day 114 it was 1.5 in $\mathrm{O}_{2}$ oversaturated water and significantly 

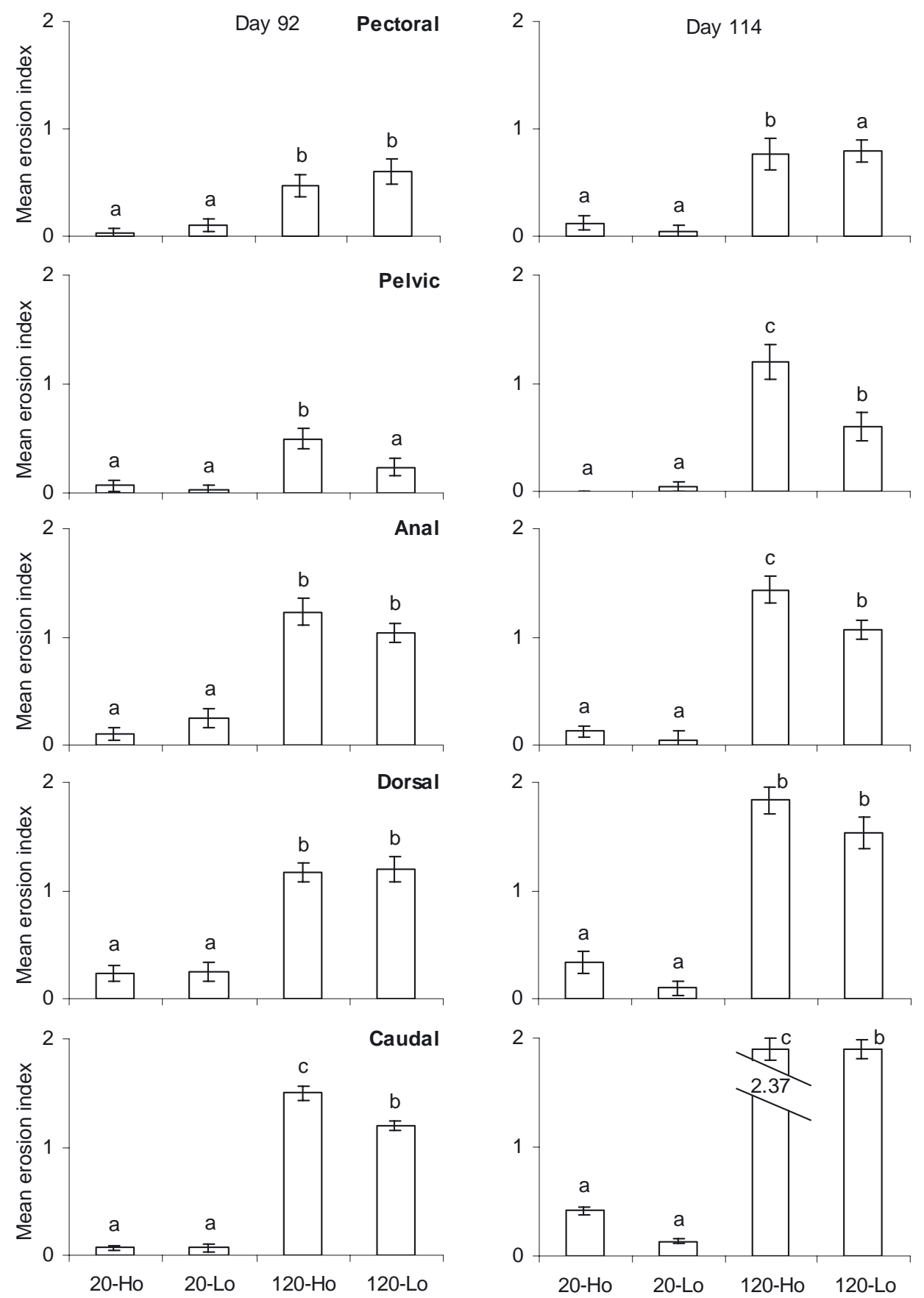

Fig. 3. Mean $( \pm \mathrm{SE})$ erosion index at days 92 and 114 of left pectoral and pelvic, posterior dorsal, anal and caudal fins according to experimental conditions (see Fig. 2 legend). Values with a different letter at the same date are significantly different.

lower (1.0) under hypoxic conditions. At low SD, perfect fins were predominant, with $90 \%$ of level 0 , and at high SD they were only $30-20 \%$. At high SD, the frequency of level 2 increased from less than $10 \%$ at day 92 to $23-42 \%$ at day 114 and was greater at the highest $\mathrm{O}_{2}$ concentrations.

In all groups, the posterior dorsal and caudal fins, that are particularly exposed to mechanical shocks during crowding, were the most eroded (Fig. 3). In the paired fins there were no significant differences in fin erosion between the right and left side, although both right pelvic and pectoral were slightly more eroded than left ones (results not shown). Splitting of the caudal fin was also noted at high SD at the end of the experiment, but there was no other major fin or skin damage (bleeding, necrosis, bolded fin rays or scale marks).

This experiment showed that long-term exposure to very high stocking densities $\left(120 \mathrm{~kg} \mathrm{~m}^{-3}\right)$ is a risk factor that may impair fin condition irrespective of $\mathrm{O}_{2}$ concentration (a water quality parameter) in the rearing environment. 

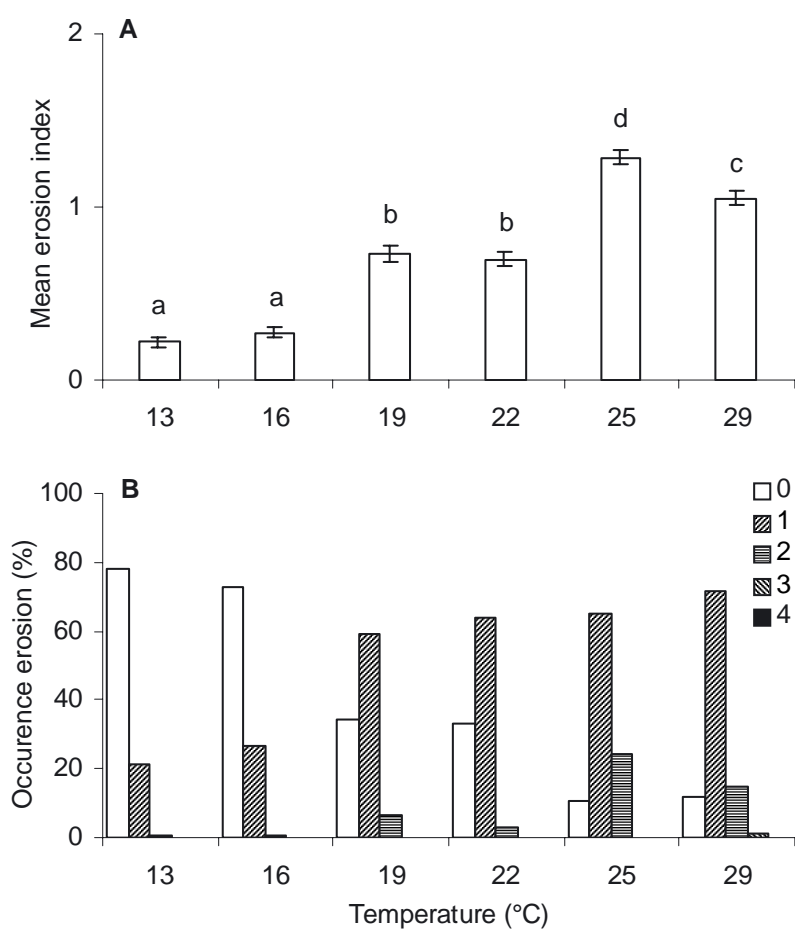

Fig. 4. Mean $( \pm$ SE) erosion index $(A)$ and erosion occurrence per level (B) at day 84 in relation to temperature. Values with a different letter at the same date are significantly different $(p<0.05)$.

\subsubsection{Temperature}

Fish in this experiment were maintained in high quality water, there was no mortality and growth was strongly affected by temperature (Table 2). No severe fin or skin damage was observed at any temperature, although all fish were individually weighed 7 times over the course of the experiment.

Fin erosion level was affected by temperature and was maximal at $25^{\circ} \mathrm{C}$ (Fig. 4). Mean erosion index was very low at $13-16{ }^{\circ} \mathrm{C}(0.22-0.25)$, but was five times higher at $25^{\circ} \mathrm{C}$. It was also significantly lower at $29^{\circ} \mathrm{C}$ than at $25^{\circ} \mathrm{C}(1.05 \mathrm{com}$ pared to 1.29$)$. At 13 and $16{ }^{\circ} \mathrm{C}$, the occurrence of level 0 was 78 and $73 \%$ respectively compared to $11-12 \%$ at $25-29{ }^{\circ} \mathrm{C}$. For level 1, it was $21-27 \%$ at $13-16{ }^{\circ} \mathrm{C}$ and about three times higher at $25-29^{\circ} \mathrm{C}$. Caudal and posterior dorsal fins were the most eroded (Fig. 5). The paired fins were slightly damaged in a similar way on the left and right sides.

This experiment showed that fin damage was greater at high temperature than in cold water (as fish were smaller, less active and with a larger space).

\subsection{Fin damage monitoring under production conditions}

\subsubsection{Intensive land-based farm}

The fish examined were representative of current market sizes (Fig. 6). For group L, stocking density range was 50 to $80 \mathrm{~kg} \mathrm{~m}^{-3}$ and fish have not been handled for grading from 6-12 months (Table 3). All fish examined looked healthy with no apparent signs of poor welfare or stress.
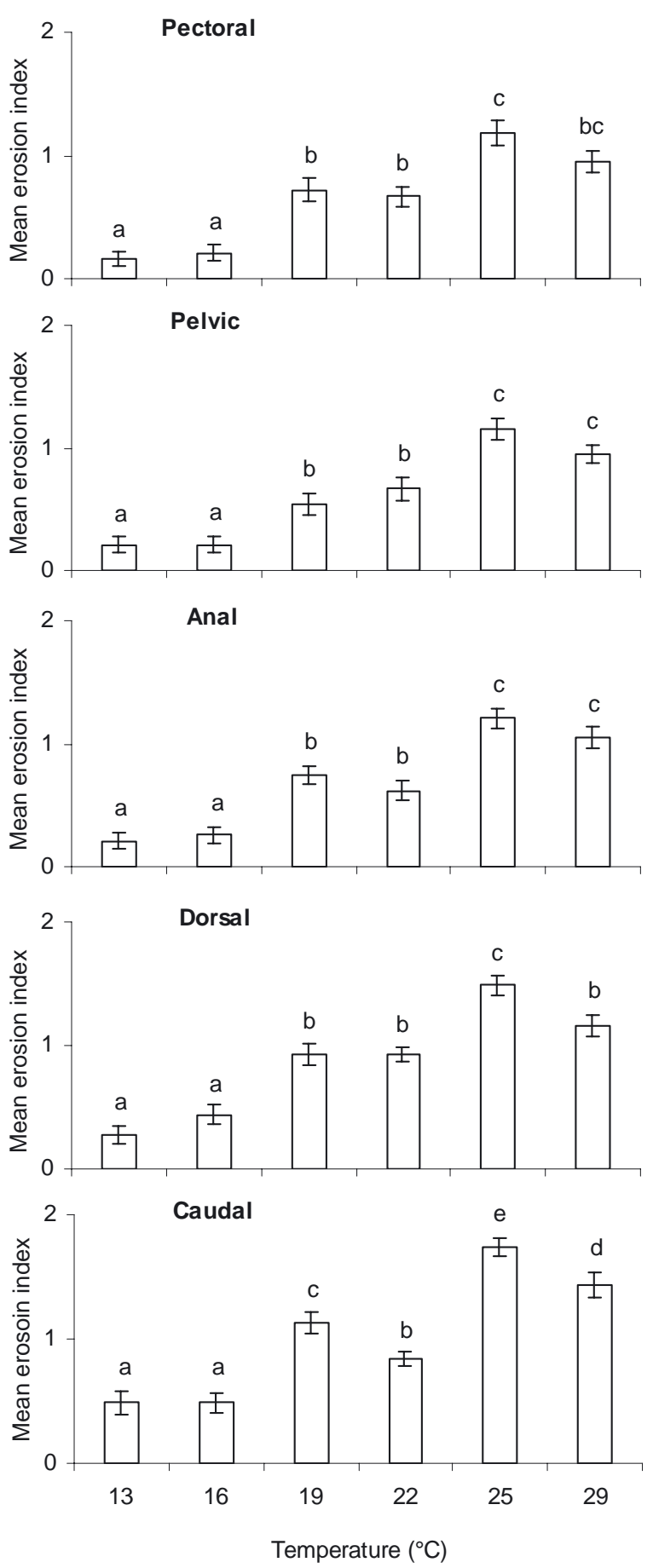

Fig. 5. Mean ( \pm SE) erosion index at day 84 of left pectoral and pelvic, posterior dorsal, anal and caudal related to temperature. Values with different letters are significantly different.

Fin condition was high and mean fin erosion index ranged from 1.1 to 1.3 . The occurrence of level 1 was $50-60 \%$ and that of level 3, 3-5\% (Fig. 7). The observed differences in fin erosion of $\mathrm{S}$ groups cannot be easily explained by differences in fish size or rearing conditions. In large fish (800-900 g) severity of fin erosion increased with stocking density. The most eroded fins were the posterior dorsal and caudal, and paired 
S
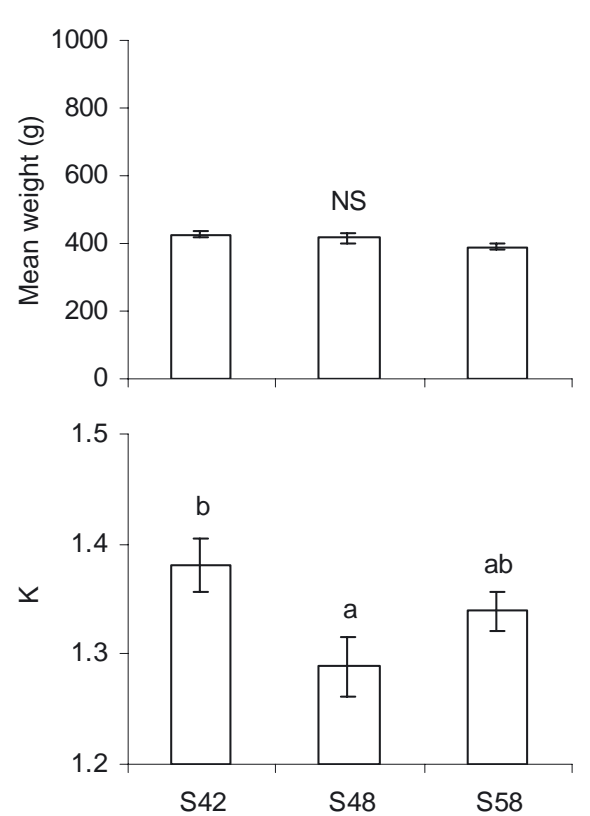

$\mathbf{L}$
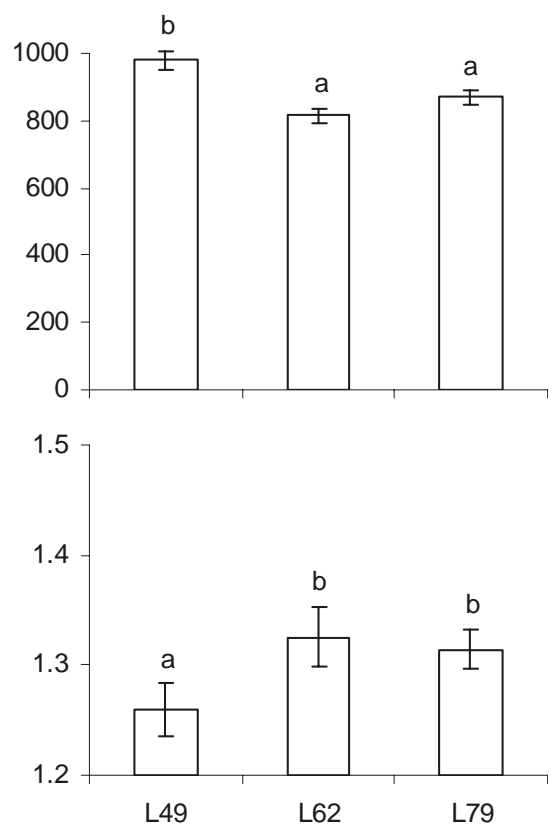

Fig. 6. Mean $( \pm$ SE) weight and condition factor $(K)$ of the 6 batches examined at the land-base farm. Values with different letters are significantly different.

fins were affected in the same way (left fin results only shown in Fig. 7).

The other external injuries observed on whole fish or specific fins are detailed in Table 4. Fin splitting was common in all batches, with split index between 0.43 and 0.63 , except in batch L79 (0.90). The caudal fin was more susceptible to splitting than the other fins: caudal splitting index was thus about 3 times higher than that for all fins. Fin ray deformities were also observed on posterior dorsal fins, with an occurrence of $25 \%$ and $60 \%$ in S and L groups, respectively. Necrosis spots were present on fins and whole body with a higher prevalence in large than in small fish. In 10-20\% of the fish, scale marks (1-2 $\mathrm{cm}^{-3}$ area with scale abnormalities resulting from recovery following scale loss) were also present on both right and left sides.

This survey showed that fin condition was high in market size fish under intensive farming conditions using both a short production cycle and high SD. There was a good correlation between split index $(y)$ and erosion index $(x)$, as shown by the regression equation: $y=1.8146 x-1.563 ; r^{2}=0.87$, suggesting that the occurrence of splits on all fins may be used as a rough indicator of fish welfare when it is not possible to assess fin erosion using the main method we describe.

\subsubsection{Sea cage farm}

In the four batches that were below the smallest market size of $300 \mathrm{~g}$, mean fin erosion index was 0.9 except in one batch (M2) where it was about 35\% higher (Figs. 8 and 9). In large fish, mean erosion index was higher (1.1-1.2), which resulted from a higher occurrence of level 2 (20-25\%) than in small fish. It was in the same range as the most highly affected batch of small fish (M2).
The fins that were the most vulnerable to erosion were the caudal, posterior dorsal and pectoral (Fig. 10). This latter result was unexpected. The observed differences in fin erosion between batches were due more to sea cage location in the bay in relation to currents and storms than to fish size (Fig. 11).

The caudal fin was also the most vulnerable to splitting: caudal split index was 3 times higher than it was for all fins together (Table 6). As in tank reared fish, split index $(y)$ was related to erosion index $(x)$ by the equation:

$$
y=0.7828 x-0.5256 ; r^{2}=0.70
$$

Fin ray deformities were low in comparison (maximum, 10 to $20 \%$ in large fish) and there was no fin necrosis in most batches. Conversely, there was a high prevalence of scale marks in all batches (20\% of the fish examined), irrespective of fish size that may result primarily from inadequate grading procedures, or specific handling difficulties in sea cages.

This monitoring showed that small fish generally had a better fin profile than large fish, and fin abrasion was lower in the sheltered areas of the bay irrespective of fish size.

\section{Discussion}

We proposed and evaluated a non invasive method to assess fin damage and especially fin abrasion in sea bass juveniles and adults, which would be easy to use on a large number of anaesthetized fish. The main difficulty in establishing such a method was the choice of a key with different degrees of erosion that would limit operator error, be adapted to both juvenile and adults, and be usable under any rearing conditions or in the wild. The 5 erosion levels proposed are based on changes in fin 

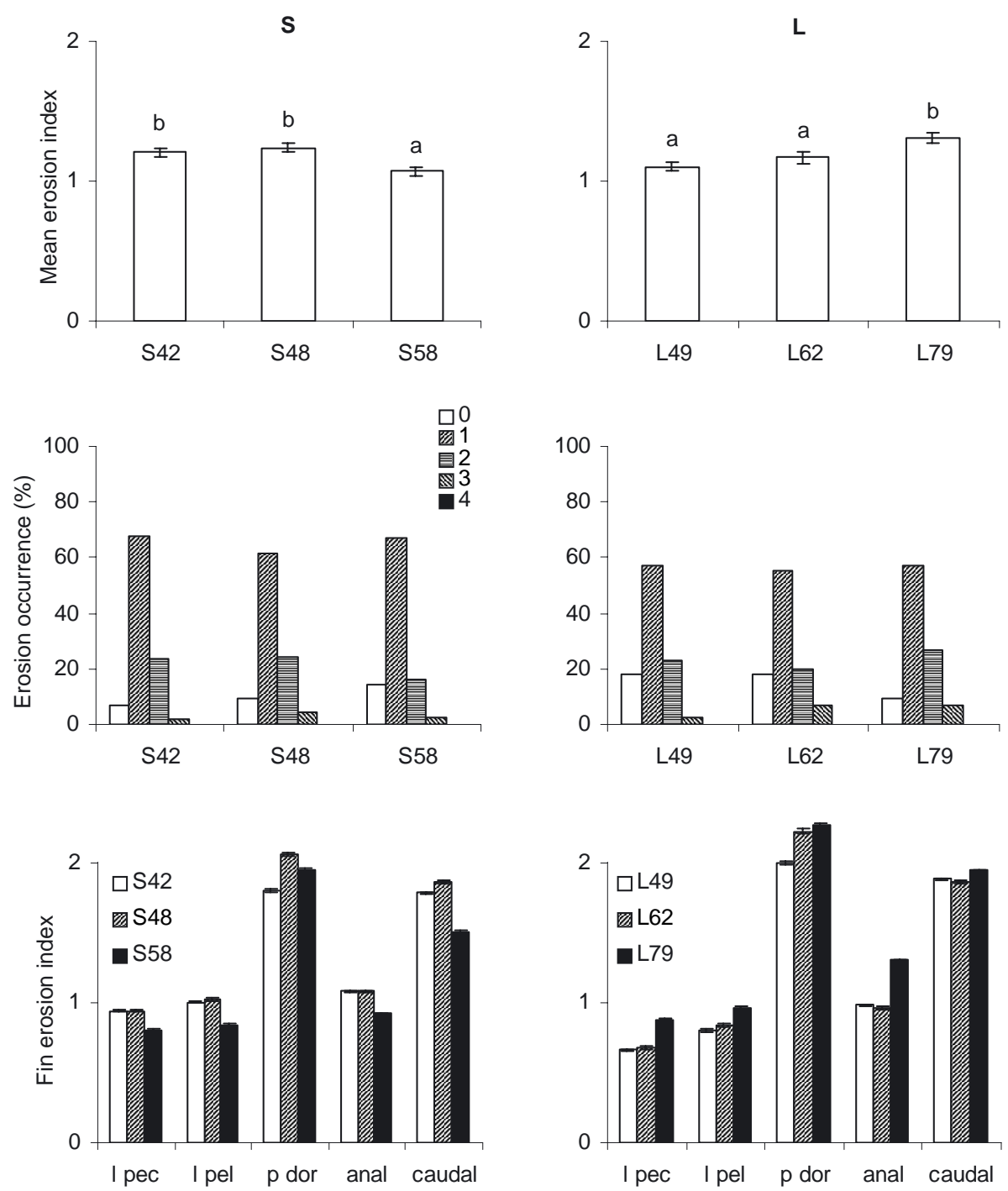

Fig. 7. Mean $( \pm \mathrm{SE}$ ) erosion index and occurrence $(\%)$ per batch and erosion index of left paired fins (pectoral, pelvic), posterior dorsal (p dor), anal and caudal in the small (S) and large (L) groups of fish examined at the land-based farm. Values with different letters are significantly different.

profile and a visual estimation of area loss of all fins with reference to a perfect fin. In comparison with other methods there is no need for fin measurement and high quality digital photos that would be both time consuming and unpractical using anaesthetized fish under some farming conditions (Hoyle et al. 2007; Ellis et al. 2009).

The method proposed was shown to be operational on farms, reliable and easy to use for an operator with limited experience; it has not yet been tested in the wild. All fins except the anterior dorsal could be rapidly examined to assign an erosion level to each. It requires careful fin splaying for comparison of a profile with a key. In experiments and on farms, 3 fins were particularly vulnerable to erosion and other damage: the caudal (active in propulsion), posterior dorsal (stabilizer, involved in maneuvering, stress and defense responses) and pectoral (involved in propulsion and reorientation). An alternative to the proposed method would be to assess fin erosion of selected fins instead of all fins, an approach applied increasingly in Salmonids (Noble et al. 2008; Person-Le Ruyet et al.
2008). Recording major splits in selected fins can also give an overview of fin damage, as proposed by Turnbull et al. 1996, but it gives no indication of fin area loss and erosion. This study has shown that the caudal fin is highly sensitive to splitting and that, at least under farming conditions, there is a good correlation between mean split index and fin erosion index.

At a laboratory scale, stocking density (SD) was identified as a major risk factor for fin erosion: erosion index was 10 times higher at 120 than at $20 \mathrm{~kg} \mathrm{~m}^{-3}$. The negative effect of high SD could not be associated with water quality (fin condition was better under hypoxic conditions) or to aggressive behavior (no bite marks). It may result from numerous factors and their interactions: limited space related to weight gain, crowding during feeding or high water velocity. It should be noted that fin condition was little impacted when SD increased from 90 to $120 \mathrm{~kg} \mathrm{~m}^{-3}$ within 4 months: all fins were fully functional with a moderate loss of fin area but no other injuries (bleeding or necrosis). Such high SD are never used over a long-period in the most intensive farming, i.e. in re-circulated 
Table 6. Additional fin and skin damage in the 8 batches examined in the sea-cage farm. Fish examined for whole body and all fins, $n=50$; split index is given for all fins and for caudal (bracket); necrosis occurrence is given for whole body and for all fins (bracket).

\begin{tabular}{|c|c|c|c|c|c|}
\hline \multirow{2}{*}{ Batch } & \multirow{2}{*}{$\begin{array}{l}\text { Mean weight } \\
(\mathrm{g})\end{array}$} & \multirow{2}{*}{$\begin{array}{c}\text { Split index } \\
\text { All fins (caudal) }\end{array}$} & \multicolumn{3}{|c|}{ Occurrence (\% of fish) } \\
\hline & & & $\begin{array}{l}\text { Whole body necrosis } \\
\text { (fin) }\end{array}$ & $\begin{array}{l}\text { Ray deformity } \\
\text { (all fins) }\end{array}$ & Scale marks \\
\hline $\mathrm{C} 22$ & 101 & $0.14(0.50)$ & $0(0)$ & 4 & 30 \\
\hline P11 & 159 & $0.17(0.54)$ & $4(0)$ & 4 & 28 \\
\hline M2 & 196 & $0.44(1.42)$ & $0(0)$ & 2 & 22 \\
\hline $\mathrm{C} 15$ & 267 & $0.21(0.40)$ & $4(2)$ & 8 & 16 \\
\hline M1 & 358 & $0.31(0.94)$ & $6(0)$ & 8 & 6 \\
\hline P7 & 408 & 0.39 (1.58) & $20(0)$ & 0 & 24 \\
\hline P3 & 474 & $0.41(1.76)$ & $8(0)$ & 10 & 22 \\
\hline P13 & 885 & $0.47(1.12)$ & $10(0)$ & 20 & 12 \\
\hline
\end{tabular}


Fig. 8. Mean $( \pm$ SE) weight and condition factor $(K)$ of the batches examined at the sea cage farm. Values with different letters are significantly different.
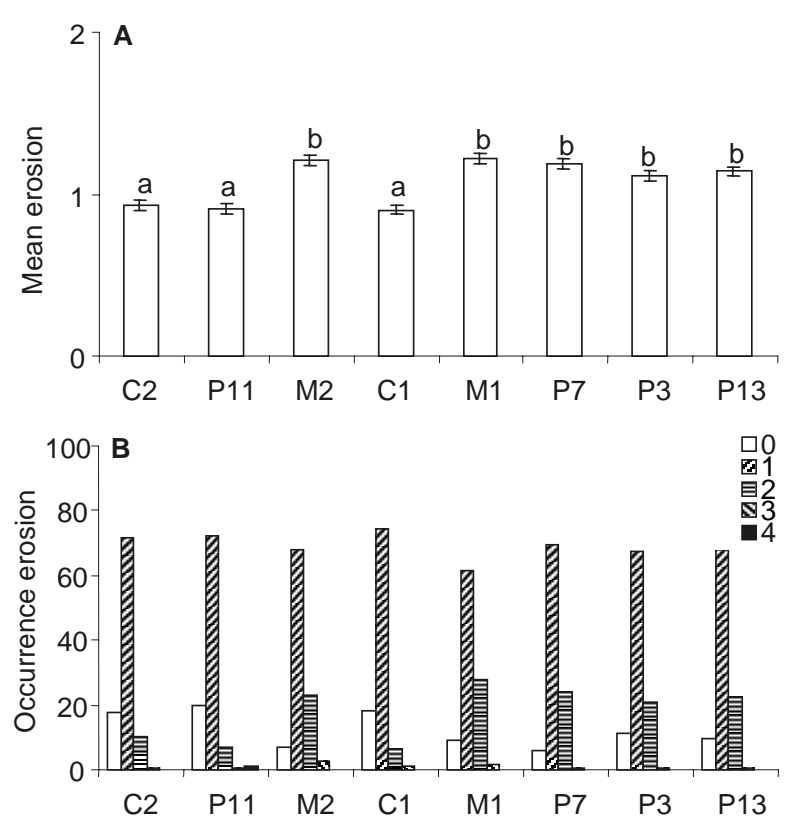

Fig. 9. Mean $( \pm$ SE) erosion index and occurrence $(\%)$ per batch examined at the sea cage farm. Values with different letters are significantly different.

systems where both SD and water velocity are high. Sammouth et al. (2009) reported that in sea bass (135 g) the highest
SD for maximum growth performances over a 63-day period in a re-circulated system was about $70 \mathrm{~kg} \mathrm{~m}^{-3}$.

It has also been shown experimentally that fin condition may be affected by metabolic activity under the control of ecological factors, such as temperature and $\mathrm{O}_{2}$ concentration acting, respectively, as determining and limiting factors. In sea bass, fins were more eroded at elevated temperature than in cold water as fish were less active, especially when feeding: meal duration was shorter and daily feed intake was lower, which led to a lower growth rate (Person-Le Ruyet et al. 2004). However fin condition may remain high at very high temperature, over the upper limit for maximum growth. Although fin damage may be reduced by decreasing rearing temperature (and thus fish activity), this may be unacceptable for economic reasons, especially in intensive systems where rapid growth is a priority. The observed differences in fin condition related to temperature may be partly explained by differences in fish size and stocking density, a better tank volume to fish size ratio leading to a lower number of physical shocks between fish or on tank walls. It would be interesting to study the kinetics of fin profile changes with temperature to better assess temperature impact on fin erosion and splitting of caudal and dorsal mainly. Fin condition was more impaired in sea bass held under high $\mathrm{O}_{2}$ concentrations than under low $\mathrm{O}_{2}$ concentrations, where fish swimming and feeding activity was lower. A previous study in rainbow trout showed that lower fin erosion in water with less $\mathrm{O}_{2}$ and more ammonia than a control group 

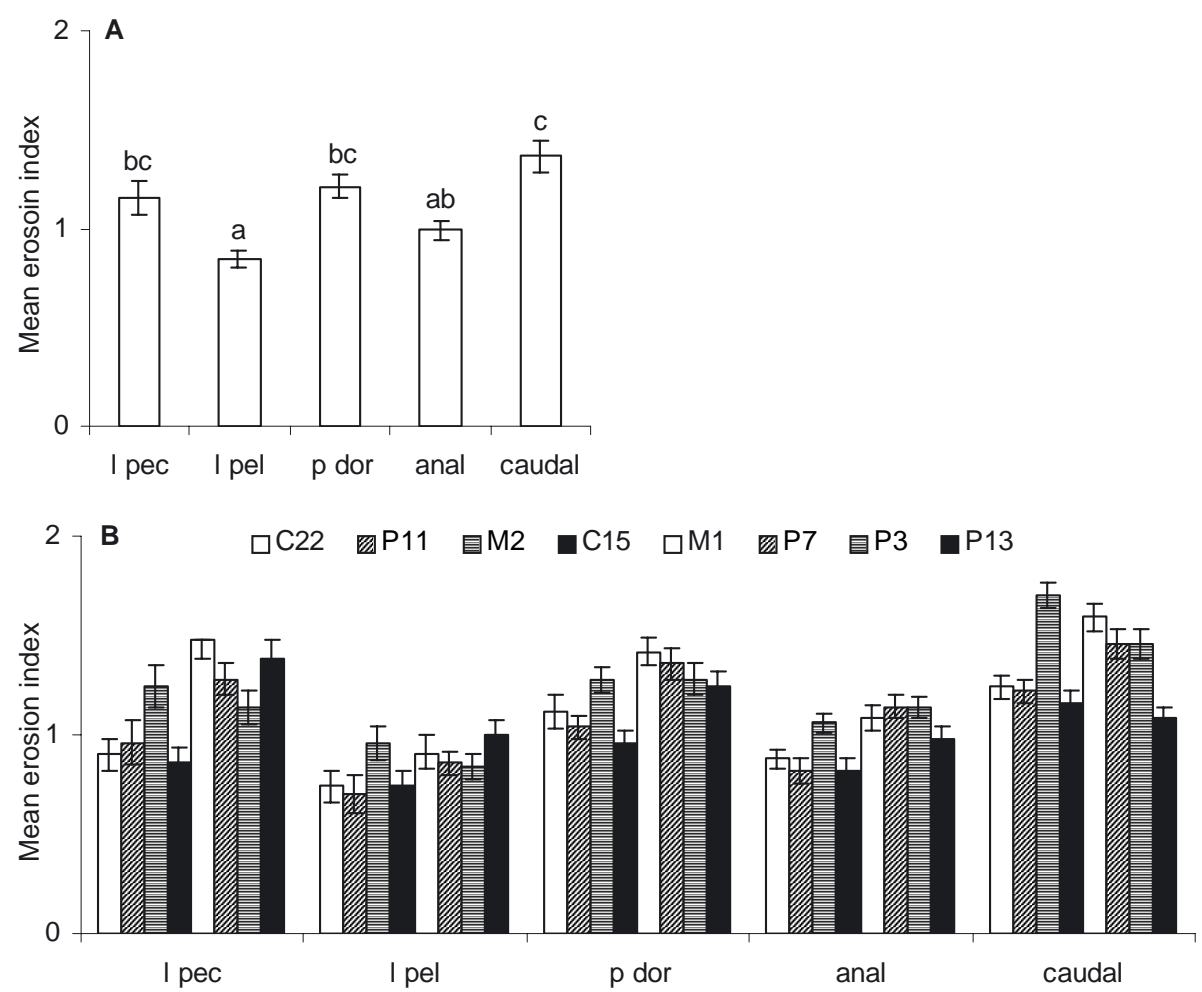

Fig. 10. Mean ( \pm SE) erosion index of left paired fins (pectoral, pelvic), posterior dorsal (p dor), anal and caudal fins of all fish examined (A) and $(B)$ for each batch examined at the sea cage farm. Values with different letters are significantly different.

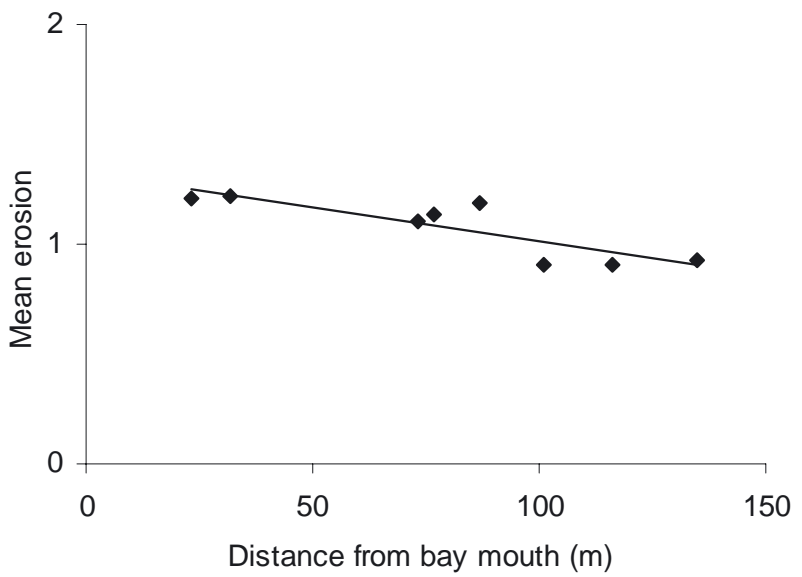

Fig. 11. The relationship of mean erosion index to sea cage location in the bay, $y=-0.0031+1.32 ; r^{2}=0.72$.

was associated with lower feeding activity (Person-Le Ruyet et al. 2008).

The changes in routine fish activity and metabolism according to water quality or environmental conditions have been extensively studied in many species, but fin condition has only been assessed for specific purposes (Latremouille 2003). At low temperatures young stages of salmonids produced in hatcheries present a longer pectoral fin, which is vital for re stocking programs (Winfree et al. 1998). In aggressive fish, any strategy decreasing agonistic behavior, such as temperature, SD or feeding regime, leads to improve fin condition (Moutou et al. 1998; MacLean et al. 2000;
Rasmussen et al. 2007; Noble et al. 2007, 2008). Using ondemand devices or a continuous food supply may improve fin condition by reducing the intensity and frequency of mechanical shocks when feeding and also by limiting aggressive behavior.

In the two sea bass farms monitored in the present study, fin condition of all batches examined was generally good, with erosion level 1 prevailing and only $20 \%$ of level 2 . The main eroded fins were the caudal and posterior dorsal, as in the experiments conducted under controlled conditions, and there were no bite marks. The two pectoral fins were more seriously damaged in sea cages than in tanks, which could result from specific behaviour and abrasion from contact with net cages due to water currents. In fish below $350 \mathrm{~g}$, fin erosion was slightly higher in sea cages than in the two experiments when a comparison was made at similar SD. For large fish, fin erosion was in the same range for the two sites irrespective of SD $\left(<25\right.$ or about $\left.60 \mathrm{~kg} \mathrm{~m}^{-3}\right)$ and production cycle duration (41 or 23 months for large fish). In the land based farm, SD was a major risk factor for fin abrasion, under specific rearing conditions of the farm a SD of $60 \mathrm{~kg} \mathrm{~m}^{-3}$ seems preferable at the end of production cycle. In sea cages, cage location was a risk factor: fin erosion was higher in the cages most exposed to currents and wind.

There were some differences in the extent of other types of damage to fins or whole fish between the two farms. The main difference was a lack of fin necrosis but low prevalence of necrosis of the whole body in sea cages, which may have been related to differences in disease occurrence, husbandry frequency or water quality. Husbandry practices may explain why fin splitting and fin ray deformities are more prevalent 
in land-based farms than in sea cages, where handling was minimized during a long production cycle. The more fish are handled, the higher the risk of inducing fin damage and tissue lesions, leading to increased risk of infection and disease especially in a confined environment. The high prevalence of scale abnormalities on the fishes' sides in both sites resulted from recovery after scale loss that had occurred during grading or routine handling. It was higher in sea cages, where handling is restricted and more difficult than in land-based farms. In comparison, regular handling of a small number of anaesthetized fish is possible in laboratory studies without causing broken fin rays, tissue lesions or necrosis.

To conclude, this study has shown that the effects of rearing conditions on fin profile changes operate in a complex way through metabolic and/or behavioral influences. Fin abrasion may be minimized by sufficient space availability and by avoiding excessive metabolic activity or stress, especially during feeding. Sea bass can be reared on farms at relatively high SD without significant fin damage, but there is a need to improve handling and grading procedures that may impair fish external appearance.

Acknowledgements. This study is a contribution to the "BENEFISH" European program. The authors would like to thank the SFAM and staff of the two farms, Aquanord and Provence Aquaculture, who took part in this study (especially F. Gaine and F. Stabholz) and are grateful to the "BENEFISH" team. The study was carried out within the financial support from the Commission of the European Communities, specific RTD programme "Specific Support to Policies", SSP-5-Fish "BENEFISH". It does not necessarily reflect the views of the commission, nor does it aim to present the Commission's future policy in this area in any way.

\section{References}

Arndt R.E., Routledge M.D., Wagner E.J., Mellethin R.F., 2002, The use of Aquamasts $囚$ to enhance growth and improve fin condition among raceway cultured rainbow trout Oncorhynchus mykiss (Walbaum). Aquac. Res. 33, 359-367.

Ashley P.J., 2007, Fish welfare: current issues in aquaculture. Appl. Anim. Behav. Sci. 104, 199-235.

Barrows F.T., Lellis W.A., 1999, The effect of dietary protein and lipid source on dorsal fin erosion in rainbow trout, Oncorhynchus mykiss. Aquaculture 180, 167-175.

Conte F.S., 2004, Stress and the welfare of cultured fish. Appl. Anim. Behav. Sci. 86, 205-223.

Damsgard B., Arnesen A.M., Baardvik B.M., Jobling M., 1997, State dependent feed acquisition among two strains of hatchery-reared Arctic charr. J. Fish Biol. 50, 859-869.

Di Marco P., Priori A., Finoia M.G., Massari A., Mandich A., Marino G., 2008, Physiological responses of European sea bass Dicentrarchus labrax to different stocking densities and acute stress challenge. Aquaculture 275, 319-328.

Ellis T., Hoyle I., Oidtmann B., Turnbull J.F., Jacklin T.E., Knowles T.G., 2009, Further development of the "fin index" method for quantifying fin erosion in rainbow trout. Aquaculture 289, 283 288.
Ellis T., Oidtmann B., St-Hilaire S., Turnbull J., North, B.P., MacIntyre C., Nikomaidis J., Hoyle I., Kestin S., Knowles T., 2008, Fin erosion in farmed fish. In: Branson E.J. (Eds.), Fish welfare, Blackwell, Oxford, pp. 121-149.

Geode R.W., Barton B.A., 1990, Organismic indices and an autopsybased assessment as indicators of health and condition of fish. Am. Fish. Soc. Symp. 8, 93-108.

Good C., Dadidson J., Welsh C., Brazil B., Snekvik K., Summerfelt S., 2009, The impact of water exchange rate on the health and performance of rainbow trout Oncorhynchus mykiss in water recirculation aquaculture systems. Aquaculture 294, 80-85.

Hatlen B., Grisdale-Helland B., Helland S.J., 2009, Growth variation and fin damage in Atlantic cod (Gadus morhua L.) fed at graded levels of feed restriction. Aquaculture 261, 1212-1221.

Hoyle I., Oidtmann B., Ellis T., Turnbull J., North B., Nikolaidis J., Knowles T.G., 2007, A validated macroscopic key to assess fin damage in farmed rainbow trout (Oncorhynchus mykiss). Aquaculture 270, 142-148.

Huntingford F.A., Adams C.E., Braithwaite V.A., Kadri S., Pottinger T.G., Sandoe P., Turnbull J.F., 2006, Current issues in fish welfare. J. Fish Biol. 68, 332-372.

Korsoen O.J., Dempster T., Fjelldal P.G., Oppedal F., Kristiansen T.S. 2009, Long-term culture of Atlantic salmon (Salmo salar L.) in submerged cages during winter affects behaviour, growth and condition. Aquaculture (in press).

Latremouille D.N., 2003, Fin erosion in aquaculture and natural environments. Rev. Fish. Sci. 11, 315-335.

MacLean A., Metcalfe N.B., Mitchell D., 2000, Alternative competitive strategies in juveniles Atlantic salmon (Salmo salar): evidence from fin damage. Aquaculture 184, 291-302.

Moutou K.a., McCarthy I.D., Houlihan D.F., 1998, The effect of ration level and social rank on the development of fin damage in juvenile rainbow trout. J. Fish Biol. 52, 756-770.

Noble C., Kadri S., Mitchell D.F., Huntingford F.A., 2008, Growth, production and fin damage in cage-held $0^{+}$atlantic salmon presmolts (Salmo salar L.) fed either a) on-demand, or b) to a fixed satiation-restriction regime: Data from a commercial farm. Aquaculture 275, 163-168.

Noble C., Kadri S., Mitchell D.F., Huntingford F.A., 2007a, The influence of feeding regime on intraspecific competition, fin damage and growth in $1^{+}$Atlantic salmon parr (Salmo salar L.) held in freshwater production cages. Aquac. Res. 38, 1137-1143.

Noble C., Mizusawa K., Suzuki K., Tabata M., 2007b, The effect of differing self-feeding regimes on the growth, behaviour and fin damage of rainbow trout held in groups. Aquaculture 264, 214 222.

North B.P., Ellis T., Davis J., Bromage N.R., 2006a, Stocking density practices of commercial UK rainbow trout farms. Aquaculture 259, 260-267.

North B.P., Turnbull J.F., Ellis T., Porter M.J., Migaud H., Bron J., Bromage N.R., 2006b, The impact of stocking density on the welfare of rainbow trout (Oncorhynchus mykiss). Aquaculture 255, 466-479.

Pelis R.M., McCormick S.D., 2003, Fin development in stream- and hatchery-reared Atlantic Salmon. Aquaculture 220, 525-536.

Person-Le Ruyet J., Labbé L., Le Bayon N., Sévère A., Le Roux A., Le Delliou H., Quéméner L., 2008, Combined effects of water quality and stocking density on welfare and growth of rainbow trout (Oncorhynchus mykiss). Aquat. Living Resour. 21, 185195. 
Person-Le Ruyet J., Le Bayon N., Gros S., 2007, How to assess fin damage in rainbow trout, Oncorhynchus mykiss? Aquat. Living Resour. 20, 191-195.

Person-Le Ruyet J., Mahé K., Le Bayon N., Le Delliou, H., 2004, Effects of temperature on growth and metabolism in a Mediterranean population of European sea bass, Dicentrarchus labrax. Aquaculture 237, 269-280.

Person-Le Ruyet J., Pichavant K., Vacher C., Le Bayon N., Sévère A., Bœuf G., 2002, Effects of $\mathrm{O}_{2}$ supersaturation on metabolism and growth in juvenile turbot (Scophthalmus maximus L.). Aquaculture 205, 373-383.

Rasmussen R.S., Larsen F.H., Jensen S., 2007, Fin condition and growth among rainbow trout reared at different sizes, densities and feeding frequencies in high-temperature re-circulated water. Aquac. Int. 15, 97-107.

Roncarati A., Melotti P., Dees A, Mordenti O., Angellotti L., 2006, Welfare status of cultured seabass (Dicentrarchus labrax L.) and seabream (Sparus aurata L.) assessed by blood parameters and tissues characteristics. J. Appl. Ichthyol. 22, 225-234.

Roque d'Orbcastel E., Person-Le Ruyet J., Le Bayon N., Blancheton J.P., 2009, Comparative growth and welfare in rainbow trout reared in recirculated and flow through rearing systems. Aquac. Eng. 40, 79-86.

Sammouth S., Roque d'Orbcastel E., Gasset E., Lemarié G., Breuil G., Marino G., Coeurdacier J.L., Fivelstad S., Blancheton J.P., 2009, The effect of density on sea bass (Dicentrarchus labrax) performance in a tank-based recirculated system. Aquac. Eng. 40, $72-78$.

Schneider, R., Nicholson, B.L., 1980, Bacteria associated with fin rot disease in hatchery-reared Atlantic salmon (Salmo salar). Can. J. Fish. Aquat. Sci. 37, 1505-1513.

St Hilaire S., Ellis T., Cooke A., North B.P., Turnbull J. F., Knowles T., Kestin S., 2006, Fin erosion on rainbow trout on commercial trout farms in the United Kingdom. Vet. Rec. 159, 446-451.

Turnbull J.F., Richards R.H., Robertson D.A., 1996, Gross, histological and scanning electron-microscopic appearance of dorsal fin rot in farmed Atlantic salmon, Salmo salar L., parr. J. Fish Dis. 19, 415-427.

Turnbull J.F., Adams C.E., Richards R.H., Robertson, D.A., 1998, Attack site and resultant damage during aggressive encounters in Atlantic salmon (Salmo salar L.) parr. Aquaculture 159, 345353.

Turnbull J.F., Bell A., Adams C.E., Bron J., Huntingford F.A., 2005, Stocking density and welfare of cage farmed Atlantic salmon: application of a multivariate analysis. Aquaculture 243, 121-132.

Wagner E.J., Routledge M.D., Intelmann S.S., 1996, Fin condition and health profiles of albino rainbow trout reared in concrete raceways with and without a cobble substrate. Progress. Fish Cult. 58, 38-42.

Winfree R.A., Kindschi G.A., Shaw H.T., 1998, Elevated water temperature, crowding, and food deprivation accelerate fin erosion in juvenile steelhead trout. Progress. Fish Cult. 60, 192-199. 